\title{
Translation of Allusions in Fortress Besieged
}

\author{
ZHANG Qun-xing \\ Beijing Information Science and Technology University, Beijing, China
}

\begin{abstract}
The wide application of Chinese and foreign allusions is a big feature of QIAN Zhong-shu's only novel and masterpiece Fortress Besieged, which was first published in 1947. The paper makes an attempt to categorize and analyze the strategies in translating allusions adopted by Jeanne Kelly and Nathan K. Mao in the only English version. The strategies include literal translation, literal translation plus endnote, literal translation plus explanation added in the text, interpretation of the implied meaning plus endnote, and interpretation of the implied meaning in the text. In particular, the strategy of literal translation plus endnote is mostly adopted. This is indicative of the translators' wish to be as faithful as possible to the source text. What's more, the literal translation strategy and use of endnotes is of a big help to communicate the Chinese culture to foreigners.
\end{abstract}

Keywords: allusion, Fortress Besieged, translation strategies

\section{Introduction}

QIAN Zhong-shu ranks among the most important writers and literary critics in the 20th-century Chinese literature field. His masterpiece and only novel of his whole life Wei Cheng (1991), with the English translation of Fortress Besieged, which was published in the year of 1980 by Indiana University Press, enjoys high reputation home and abroad. The theme of the novel derives from a French old saying which reads "people who are outside the fortress want to break into it, while those who are trapped in the fortress desire to escape". It is a comedy of manners with much picaresque humor, as well as a scholar's novel, a satire, a commentary on courtship and marriage, and a study of one contemporary man. It can be compared to The Scholars (1749) in the 1940s of China. Hsia (1961) highly praised the novel's comic exuberance and satire, acclaiming it as "the most delightful and carefully wrought novel in modern Chinese literature; it is perhaps also its greatest novel” (p. 441).

QIAN Zhong-shu, from a special perspective, offers a realistic description of the contradictory state of mind and character flaws of the middle-class Chinese intellectuals deeply influenced by the Western and Chinese cultures in the Republican era. QIAN's enormous knowledge, rich imagination, and humorous satire make a vivid impression on readers of one generation after another. In particular, the wide use of Chinese and foreign allusions stands out as a big feature of Fortress Besieged, making it a unique literary masterpiece in China's modern literature history. The application of allusions helps to depict characters, stimulate plot development, highlight the ironic effect, and deepen the theme of the novel.

ZHANG Qun-xing, associate professor, Foreign Languages School, Beijing Information Science and Technology University. 


\section{Definition of Allusion}

Allusions have long been cherished as the crystallization of specific cultures. According to Webster's New Collegiate Dictionary (1973), allusion is an implied or indirect reference to someone or something. Barton and Hudson (1997) defines allusion as "an indirect or explicit reference by one text to another text, to a historical occurrence, or to myths and legends" (p. 9). Leppihalme (1997) defines allusion as "a figure of speech that compares aspects or qualities of counterparts in history, mythology, scripture, literature, popular or contemporary culture" (p. 6). As Wheeler (1979) puts it, "allusion helps to elucidate the meaning of each text and to indicate the literary modes and conventions in which its author works” (p. 5). Allusions have been widely applied in literature as one figure of speech. When an allusion is incorporated into another context, it acquires a double meaning, and its original meaning gives way to the secondary meaning closely related to the context. In short, allusion is an economical means of calling upon history, mythology, Holy Scriptures and other literary works that author and reader are assumed to share (Dastjerdi \& Sahebhonar, 2008).

Allusions usually derive from such origins as historical events, mythology, literary works, popular legend or folklore, fables, customs, and old sayings. The writer who adopts an allusion not only reuses the language of the original source, but also deliberately intends that the reader should recover the source context and appreciate the semantic interplay between the original and the new use. Apparently, allusions, as culture-bound elements, resist translation, and rendering them successfully depend largely on the translator's familiarity with their reference. Thus, allusion poses a troublesome challenge for translators. The famous Israeli translation theorist Lefevere (1992) argues that allusion is what cultures "develop their own shorthand", and its translation points to "the final, real aporia” (p. 56). Translating allusions is a demanding task due to the fact that allusions have specific meanings in the culture and language in which they arise but not necessarily in others. Allusive meaning is likely to be lost in translation from one language into another if only the surface referential sense is rendered into the target language. Translation of allusions, thus, involves two language cultures as well as literary and pragmatic aspects on the textual level. Indeed, translating allusions is a challenging task. Without appropriate translation, allusions may turn out to be the cause of much confusion for target readers especially when they know little about the source language and culture.

\section{Translation Strategies of Allusions in Fortress Besieged}

Since its publication in 1947, Fortress Besieged has been translated into English, French, Japanese, German, Russian, and some other languages. The English version, issued in 1979, is a joint effort of Jeanne Kelly and Nathan K. Mao. Their translation has made Fortress Besieged the first Chinese novel ever listed in the Penguin Classics.

According to statistics, there are more than 100 allusions descending from many sources in the novel. Some derive from ancient stories, including fairy tales, legends, historical events, religious stories, fables, and so forth; some come from poetic lines, statements of literary classics home and abroad, like works of ancient philosophers such as Confucius, Sijing (The Book of Songs) (n.d.), The Bible (n.d.), Aesop's Fables (n.d.), Arabian Nights (n.d.), and etc.; some develop from the names of famous historical figures, names of places and things, people's titles, and so on; and some are from proverbs and old sayings. The content of the allusions also covers a wide range, including literature, philosophy, religion, medicine, biology, and military tactics. The wide use of allusions 
in Fortress Besieged makes it an extremely challenging job to translate. The English version Fortress Besieged can be regarded as a good example of literal translation. Generally speaking, most of the allusions are translated literally. Annotation, endnote in particular, is another widely used strategy. Besides, interpretation of the implied meaning directly in the text is also used by the translators. In the following, the specific strategies adopted in the English version will be analyzed with examples.

\section{Literal Translation}

When it comes to some allusions originating from Chinese ancient stories or poems, translators translate literally (see example (1)-(3)):

（1）他心境不好，准责备儿子从前不用功，急时抱佛脚，也许还来一堆“亡羊补牢，教学相长”的 教训, 更受不了。(QIAN, 1991, p. 202)

If his father were in a bad mood, he would undoubtedly rebuke him for not having studied harder before and only cramming everything in at the last minute. There might even be admonitions about "Repairing the fold after the sheep are lost”, or “One learns as one teachers” (Kelly \& Mao, 2011, p. 210).

(2) 这真是“有缘千里来相会” 了。(QIAN, 1991, p. 4)

It is certainly a case of "fate bringing people together from a thousand li away" (Kelly \& Mao, 2011, p. 6).

（3）他虽然知道唐人“欲穷千里目，更上一层楼”的好诗，并没有乘电梯。(QIAN, 1991, p. 303)

Tough he knew the lovely T'ang poem, “For a thousand li view, ascend another flight of stairs", he did not take the elevator (Kelly \& Mao, 2011, p. 316).

QIAN Zhong-shu not only used Chinese allusions, but also well knew English ones. As to those familiar to English readers, the translators directly adopt literal translation (see example (4)-(5)):

(4)“也许人家讲你像狐狸，吃不到葡萄就说葡萄酸。”(QIAN, 1991, p. 132)

"Some people might say you are like the fox who couldn't reach the grapes and complained that they were sour” (Kelly \& Mao, 2011, p. 137).

(5) 上第一课，他像创世纪里原人阿大(Adam)唱新生禽兽的名字，以后他连点名簿子也不带了。 (QIAN, 1991, p. 201)

At the first class Hung-chien was like Adam in the Book of Genesis calling out the names of the newly created animals. After that, he didn’t even bring his roll book (Kelly \& Mao, 2011, p. 208).

The allusion adopted in Example 1 comes from Aesop's Fables, "The Fox and the Grape”, which is a well-known story to the western readers. In Example 2, Adam and Book of Genesis are household names to English speakers. Therefore, word for word translation would not hinder the readers' understanding.

\section{Literal Translation Plus Endnote About Background Information}

Endnote is a commonly used translation compensation strategy, especially in translating culture-bound elements. A great number of allusions applied in the novel are closely related to ancient Chinese culture. Translators offered many endnotes to introduce to target readers the relevant background information, including the origins, related stories or persons, after literally translating the allusions in the text (see example (6)-(8)):

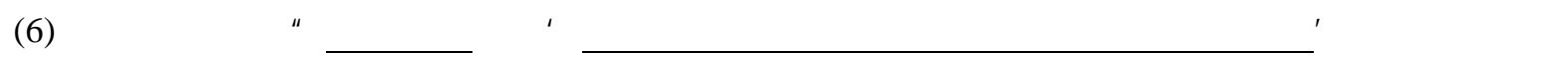
是地道中国文化的表现。” (QIAN, 1991, p. 80)

“As the poem from the Book of Odes goes, 'The noble young lady,/Waking and sleeping he sought her;/He 
sought her but could not find her,/Waking and sleeping he longed for her'. His letters are a manifestation of genuine Chinese culture”, Hung-chien said with a grin (Kelly \& Mao, 2011, p. 83).

Endnote: Literally, to harbor the amorous thoughts of spring. An allusion from the Book of Odes (Shi jing), a collection of 305 songs dating from about 1100 to 600 B.C. The arrangement is attributed to Confucius, who considered the book a model of poetic expression (Kelly \& Mao, 2011, p. 360).

(7) 鸿渐给酒摆布得失掉自制力道 : “反正你会摆空城计”。(QIAN, 1991, p. 89)

Under the influence of alcohol, Hung-chien had lost his self-control, as he blurted out, "Anyway, you could always pull the 'empty-town bluff'” (Kelly \& Mao, 2011, p. 91).

Endnote: A reference to a story in the Romance of the Three Kingdoms in which Chukuo Liang, left to defend a town with no soldiers, feigned nonchalance by playing music in the tower on the town walls to give the enemy commander the impression that the town was confident and well prepared for an attack (Kelly \& Mao, 2011, p. 363).

（8）遜翁一天听太太批评亲家母，灵感忽来，日记上添上了津彩的一条，说他现在才明白为什么两 家攀亲要叫“结为秦晋” …… (QIAN, 1991, pp. 299-300)

One day after hearing his wife criticize Mrs. Sun, Tun-weng in a sudden inspiration added a splendid passage to his diary stating that now at last he understood why two families seeking a marriage alliance called it “joining together as Ch’in and Tsin” (Kelly \& Mao, 2011, p. 312).

Endnote: During the Ch'un Ch'iu period (722-481 B.C.), the royal families of the states of Ch'in and Tsin formed marital alliances one generation after another. Thus the phrase, "joining together as Ch'in and Tsin", means to be allied in marriage (Kelly \& Mao, 2011, p. 373).

\section{Literal Translation Plus Endnote Serving as Explanation}

In some endnotes, translators offer a clearer explanation about the meaning of the allusion without presenting the relevant historical or cultural information. In the text its literal meaning is translated (see example (9)-(11)):

（9）苏小姐理想的自己是：“艳如桃李，冷若冰霜，” …… (QIAN, 1991, p. 13)

Miss Su, who pictured herself in the words of the familiar saying, "as delectable as peach and plum and as cold as frost and ice”, ... (Kelly \& Mao, 2011, p. 16).

Endnote: A standard description of a woman who appears cold and stern. It usually describes a virtuous maiden or widow (Kelly \& Mao, 2011, p. 355).

(10) 以后飞机接连光顾, 大有绝世侍人一顾倾城、再顾倾国的风度。(QIAN, 1991, p. 36)

Later, the planes kept coming in much the same manner as the peerless beauty whose "one glance could conquer a city and whose second glance could vanquish an empire” (Kelly \& Mao, 2011, p. 40).

Endnote: An expression which describes superlative beauty; it is equivalent of Helen of Troy in Western literature (Kelly \& Mao, 2011, p. 358).

(11) 鸿渐道：“啊吆约，你又来了! 朋友只好绝交。你既然不肯结婚, 连内助也没有，真是“赔了 夫人又折朋' 。” (QIAN, 1991, p. 278)

“Ai yo! There you go again. I might as well cut off my friends. Since you refuse to get married, I don’t even have a wife. It's a true case of 'Losing a wife, and having one’s friendship destroyed'”' (Kelly \& Mao, 2011, p. 289). 
Endnote: Losing at both ends, from a story in the Romance of the Three Kingdoms. (Kelly \& Mao, 2011, p. 372)

\section{Literal Translation Plus Explanation Added In the Text}

Translators, on several occasions, directly explained a few allusions to make a supplement to help target readers understand the true meaning (see example (12)-(14)):

(12) 他所说的“让她三分”，不是“三分流水七分尘”的“三分”，而是“天下只有三分月色” 的“三分”。(QIAN, 1991, p. 107)

The "three parts" referred to in "give in to her three parts" was not the "three parts" of "three parts water, seven parts dust", but rather the "three parts" as in "There are but three parts moonlight in all the world", which simply means total surrender (Kelly \& Mao, 2011, p. 109).

(13) “这次走路真添了不少经验。总算功德圆满, 取经到了西天…… (QIAN, 1991, p. 179)

“... we’ve really gained a lot of experience during this trip. Ultimately everything came out well, and we reached the Western Paradise [Buddhist heaven]...” (Kelly \& Mao, 2011, p. 186).

（14）斜川笑道：“别胡闹，我对教书没有兴趣，“若有水田三百亩，来年不作猢狲王”；你们为 什么不陪我到香港去找机会?” (QIAN, 1991, p. 123)

"Don’t by silly”, said Hsieh-chiuan with a smile, “I’ve no interest in teaching. As they say, 'If I had three hundred mou of paddy fields, I wouldn’t be a monkey king [i.e., teacher] next year’. Why don't you both go to Hong Kong with me and look for something there?” (Kelly \& Mao, 2011, p. 126).

\section{Interpretation of the Implied Meaning Plus Endnote}

As to some allusions of a typical Chinese tradition, like Buddhism, translators directly explain the implied meaning in the text with endnotes made to introduce some relevant cultural information (see example (15)-(16)):

（15）只可惜这些事实虽然有趣，演讲时用不着它们，该另抱佛脚。(QIAN, 1991, p. 33)

Such a pity that while these items of information were all very interesting, they could not be used in the lecture. He would have to read something else (Kelly \& Mao, 2011, p. 36).

Endnote: Literally, "clasp the feet of Budda". The idiom means that when someone gets into trouble through lack of due preparation, he seeks help at the last critical moment (Kelly \& Mao, 2011, p. 357).

(16) 这事不成，李梅亭第一个说“侥幸”，还说：“失马安知非福。….” (QIAN, 1991, p. 66)

When the plan fell through, Li was the first to say, "Thank God”, adding, "It may be a blessing in disguise..." (Kelly \& Mao, 2011, p. 170).

Endnote: Literally, "just like the old frontiersman losing a horse, who knows but that which seems a misfortune may be a blessing in disguise” (Kelly \& Mao, 2011, p. 354).

\section{Interpretation of the Implied Meaning}

Some allusions are translated by directly explaining the implied meaning without endnotes added outside the text. But this strategy is seldom applied (see example (17)-(20)):

(17) 那女人平日就有一种孤芳自赏、落落难合的神情一一宴会上没人敷衍的来宾或喜酒席上过 时未嫁的少女所常有的神情一一此刻更流露出嫌恶, 黑眼镜也遮盖不了。(QIAN, 1991, p. 3)

Ordinarily the young woman had a rather conceited, aloof expression, much like that of a neglected guest at a large party or an unmarried maiden at a wedding feast (Kelly \& Mao, 2011, p. 5). 
(18) “换句话说，像方先生这样聪明，是喜欢目不识丁的笨女人。” (QIAN, 1991, p. 75)

In other words, someone as intelligent as Mr. Fang would prefer a stupid, illiterate woman. (Kelly \& Mao, 2011, p. 78).

（19）辛楣道：“今天本来也请了董太太，董先生说她有事不能来。董太太是美人，一笔好中国画， 跟我们这位斜川兄真是珠联璧合。”(QIAN, 1991, p. 84)

Hsin-mei said, "I also invited Mrs. Tung, but Mrs. Tung said she was too busy to come. Mrs. Tung is a beauty and a good painter. She and Hsieh-ch'üan make a perfect couple” (Kelly \& Mao, 2011, p. P86).

(20) “…… 莫遣佳期更后期’ ，这话很有道理。…..” (QIAN, 1991, p. 223)

“...As they say, 'Don’t put off what is best done now'. That's quite right...” (Kelly \& Mao, 2011, p. 231).

\section{Conclusions}

Most of the allusions in Fortress Besieged are classical, historical, literary, and cultural allusions which are not to be understood from superficial perusal. In the English translation, Kelly and Mao mainly adopt the strategy of literal translation plus endnote. This is indicative of the translators' wish to be as faithful as possible to the source text. More than 200 endnotes facilitate the readers' understanding of the novel. Without them, QIAN's fabulous satire would at times become inaccessible to comprehension. Besides, the literal translation strategy is also of a big help to communicate the Chinese culture to foreigners.

\section{References}

Barton, E., \& Hudson, A. (1997). A contemporary guide to literary terms with strategies for writing essays about literature. Boston and New York: Houghton Mifflin Company.

Dastjerdi, H. V., \& Sahebhonar, S. (2008). Lost in translation: An intertextual study of personal proper-name allusions. Across Languages and Cultures, 9(1), 41-55

Hsia, C. T. (1961). A history of Modern Chinese fiction. New Haven, Conn.: Yale University Press.

Lefevere, A. (1992). Translation, rewriting and the manipulation of literary fame. London and New York: Routledge.

Leppihalme, R. (1997). Culture bumps: An empirical approach to the translation of allusions. Clevedon: Multilingual Matters Ltd. QIAN, Z. S. (1991). Wei Cheng. Beijing: People’s Literature Publishing House.

QIAN, Z. S. (2011). Fortress Besieged. (J. Kelly, \& N. K. Mao. Trans.). Beijing: Foreign Langauge Teaching and Research Press. Wheeler, M. (1979). The art of allusion in Victorian fiction. London: Macmillan Press Ltd.. 